\title{
Isolation and Characterization of an Extracellular Lipase from the Conidia of Neurospora crassa
}

\author{
By MANIKUNTALA KUNDU, JOYOTI BASU, MRITYUNJAY \\ GUCHHAIT AND PARUL CHAKRABARTI* \\ Department of Chemistry, Bose Institute, 93/1 APC Road, Calcutta 700009, India
}

(Received 23 July 1986; revised 11 August 1986)

\begin{abstract}
A triacylglycerol lipase (EC 3.1.1.3) from the conidia of Neurospora crassa was purified and characterized. The enzyme was purified by Sephadex G-100 column chromatography. Homogeneity was checked by PAGE, and isoelectric focusing gave a single band corresponding to a $\mathrm{pI}$ of 6.4. The enzyme had an apparent $M_{\mathrm{r}} 54000 \pm 1000$ as determined by gel filtration. SDS-PAGE gave a single band of $M_{\mathrm{r}} 27000$, suggesting the presence of two identical subunits. This lipase preferred triglycerides with $\mathrm{C}_{16^{-}}$and $\mathrm{C}_{18}$-fatty acyl chains. It cleaved only the primary groups of triglycerides. The lipase also exhibited a marked preference for substrates containing endogenously occurring fatty acids and so may prove useful in detailed studies on the physiological relevance of fatty acyl specificity of lipases. The enzyme was not affected by detergents, or thiol-binding agents. Modification of free amino groups caused $90 \%$ inhibition, suggesting a role of these groups in the maintenance of lipase activity.
\end{abstract}

\section{INTRODUCTION}

Hydrolytic enzymes are essential for the utilization of carbon sources during germination of fungal conidia. In the conidia of Neurospora crassa three such enzymes, namely trehalase (Hanks $\&$ Sussman, 1969), invertase and $\beta$-arylglucosidase (Eberhart \& Beck, 1970, 1973), are induced to facilitate germination. Triglycerides (TGs) which are considered to be storage forms of energy, are rapidly utilized during germination of fungal conidia and plant seeds, hence it is important to understand the nature and properties of the lipases responsible.

In spite of the increasing interest in microbial lipases, very few studies have been done on fungal lipases (Semeriva et al., 1967; Tsujisaka et al., 1973; Tomizuka et al., 1966). We have previously reported the presence of phospholipases in the conidia of $N$. crassa (Chakravarti et al., 1981). Phospholipase activities have also been detected in the late stationary phase of its mycelial growth (Chakravarti et al., 1980). In the present paper we report the isolation and characterization of a triacylglycerol lipase from the same organism, the presence of which has been detected earlier (Guchhait et al., 1983).

\section{METHODS}

Reagents. Glycerol tri $\left[9,10-{ }^{3} \mathrm{H}\right]$ oleate was obtained from Amersham; TGs, acrylamide, bisacrylamide, $N, N, N^{\prime}, N^{\prime}$-tetramethylethylenediamine (TEMED), Triton X-100, trinitrobenzenesulphonic acid, (TNBS), $N$ ethylmaleimide (NEM), p-chloromercuribenzoic acid (PCMB) and 5,5'-dithiobis(2-nitrobenzoic acid) (DTNB) were from Sigma; silica gel was from Merck; $M_{\mathrm{r}}$ markers, pI calibration kit and Sephadex G-100 were from Pharmacia and ampholines ( $\mathrm{pH} 3 \cdot 5-10 \cdot 0)$ were from LKB Produkter. All other reagents were of analytical grade.

Purification of lipase. Stock culture of wild-type $N$. crassa ITCCF 1701, mating type A, was obtained from the Indian Agricultural Research Institute, New Delhi. The organism was grown at $30^{\circ} \mathrm{C}$ for $6-7 \mathrm{~d}$ on Dox and

Abbreviations: TEMED, $N, N, N^{\prime}, N^{\prime}$-tetramethylethylenediamine; TNBS, trinitrobenzenesulphonic acid; NEM, $N$-ethylmaleimide; PCMB, p-chloromercuribenzoic acid; DTNB, 5,5'-dithiobis(2-nitrobenzoic acid); TG, triglyceride; MG, monoglyceride; FFA, free fatty acid. 
Thom's modification of Czapek's medium as described previously (Chakravarti et al., 1981). Bacto Agar (2\%, $\mathrm{w} / \mathrm{v}$ ) was used to solidify the growth medium. Conidia were harvested, suspended in $0.9 \% \mathrm{NaCl}$, filtered through glasswool and kept in ice-cold $0.9 \% \mathrm{NaCl}$ for $1 \mathrm{~h}$ to leach out the extracellular enzymes. The conidial suspension was centrifuged at $20000 \mathrm{~g}$ for $15 \mathrm{~min}$ at $4{ }^{\circ} \mathrm{C}$ and an orange supernatant was obtained. It was treated with activated charcoal $\left(50 \mathrm{mg} \mathrm{ml}^{-1}\right)$ for $30 \mathrm{~min}$ at $4{ }^{\circ} \mathrm{C}$ to remove pigments and centrifuged at $20000 \mathrm{~g}$ for $10 \mathrm{~min}$ at $4{ }^{\circ} \mathrm{C}$. The colourless supernatant was lyophilized and stored at $-20^{\circ} \mathrm{C}$. Lyophilized material was dialysed against $0.1 \mathrm{M}$-sodium phosphate buffer $(\mathrm{pH} 7.0)$ and fractionated on Sephadex G-100 $(1.6 \times 70 \mathrm{~cm})$. Proteins were eluted with $0.1 \mathrm{M}$-sodium phosphate buffer $(\mathrm{pH} 7.0)$ at a flow rate of $0.25 \mathrm{ml} \mathrm{min}{ }^{-1}$ and $1.5 \mathrm{ml}$ fractions collected at $4{ }^{\circ} \mathrm{C}$. One unit of enzyme activity (U) was defined as the amount that liberated $1 \mu \mathrm{mol}$ free fatty acid (FFA) $\mathrm{min}^{-1}$ at $30^{\circ} \mathrm{C}$. Fractions having lipase activity greater than $10 \mathrm{U} \mathrm{ml}^{-1}$ were pooled, lyophilized, dialysed against $50 \mathrm{~mm}$ Tris/ $\mathrm{HCl}\left(\mathrm{pH} \mathrm{7.0)}\right.$ and stored at $-20^{\circ} \mathrm{C}$ before use in subsequent studies. The protein content was measured by the Lowry method using BSA as standard.

Homogeneity was assessed by disc gel electrophoresis at pH 8.3 (Davis, 1964) and by SDS-PAGE (Weber \& Osborn, 1969). Isoelectric focusing was performed on $5 \%$ polyacrylamide gels using ampholines (pH 3.5-10.0) and the broad pI calibration kit (Wrigley, 1976). The $M_{\mathrm{r}}$ of the lipase was determined by Sephadex G-100 column chromatography using BSA (67000), ovalbumin (43000) and chymotrypsinogen A (25000) as $M_{\mathrm{r}}$ markers.

Lipase assay. TG-hydrolase activity was measured using glycerol tri $\left[9,10^{-3} \mathrm{H}\right]$ oleate (specific activity $0.5 \mathrm{mCi} \mathrm{mmol}^{-1} ; 7.4 \mathrm{TBq}$ ) dispersed in Triton X-100. The assay mixture, containing $10 \mathrm{mg}$ Triton X-100 ml-1, $3 \mathrm{~mm}$-triolein, $20 \mathrm{~mm}-\mathrm{CaCl}_{2}$ and $50 \mathrm{~mm}-\mathrm{Tris} / \mathrm{HCl}(\mathrm{pH} \mathrm{7.0})$ in a final volume of $5 \mathrm{ml}$, was emulsified by sonication. The enzyme was added and the mixture was incubated for $30 \mathrm{~min}$ at $30^{\circ} \mathrm{C}$. The reaction was stopped by adding Dole's extraction mixture (Dole \& Meinertz, 1960). The heptane phase was subjected to TLC using silica gel and $\mathrm{n}$-hexane/diethyl ether/acetic acid $\left(80: 20: 1\right.$, by vol.) as the developing solvent. The liberated $\left[9,10-{ }^{3} \mathrm{H}\right]$ oleic acid was scraped off and measured by liquid scintillation counting (LKB Mini-Beta 1211). Triton X-100 at the above concentration did not affect lipase activity. Non-radioactive substrates were dispersed at the same concentration as above and the assay conditions were also the same. The FFA liberated was measured by titration with $\mathrm{NaOH}$ after dilution with ethanol (Brockerhoff \& Jensen, 1974a). To obtain a good dispersion, tripalmitin and tristearin were first dissolved in a few drops of chloroform before emulsification in assay buffer containing Triton X-100. After emulsification, the chloroform was evaporated from the substrate emulsion in a stream of $\mathrm{N}_{2}$ (Lin \& Huang, 1983).

For qualitative determination of lipase activity, TGs obtained from lard were used as a substrate and the components of the reaction mixture were separated by TLC as described above. The fatty acid composition of monoglycerides and FFAs liberated by the hydrolysis of lard TGs with the $N$. crassa lipase was determined according to the method of Luddy et al. (1960). Methyl esters were analysed by GLC in a Pye Unicam, 104 series gas chromatograph fitted with a dual flame ionization detector on a $10 \%$ polyethylene glycol adipate column (100$120 \mathrm{mesh})$ at $170^{\circ} \mathrm{C}$.

All results are mean values of five separate determinations (SE $\pm 5 \%$ ).

\section{RESULTS AND DISCUSSION \\ Purification of lipase}

The triacylglycerol lipase activity was purified by Sephadex G-100 column chromatography as shown in Fig. 1. The fractions having lipase activity greater than $10 \mathrm{U} \mathrm{ml}^{-1}$ (fractions $51-53$ ) were pooled. By this method the lipase was purified 26 -fold with a specific activity of $44 \mathrm{U}$ (mg protein) $)^{-1}$ (Table 1). The lipase thus purified showed a single band after PAGE (Fig. $2 a$ ) and isoelectric focusing (Fig. $2 d$ ) with a pI of 6.4 , thereby confirming the homogeneity of the protein. Gel filtration on Sephadex G-100 gave an apparent $M_{\mathrm{r}} 54000 \pm 1000$. SDS-gel electrophoresis in the absence as well as in the presence of 2-mercaptoethanol showed a single band corresponding to an $M_{\mathrm{r}} 27000$, suggesting that the lipase contains two subunits of $M_{\mathrm{r}}$ 27000 each, which are not associated by disulphide bonds (Fig. $2 c$ ).

\section{Properties of the enzyme}

The $N$. crassa lipase showed optimum activity at $30{ }^{\circ} \mathrm{C}$ which was reduced by some $60 \%$ at $45^{\circ} \mathrm{C}$. The optimum $\mathrm{pH}$ for activity was about 7 , and activity was barely detectable at $\mathrm{pH} 5.5$ and $8 \cdot 5$. The $N$. crassa lipase-mediated hydrolysis of triolein was stimulated by $20 \mathrm{mM}-\mathrm{Ca}^{2+}$, but it was unaffected by $\mathrm{Mg}^{2+}$ under the same conditions. $\mathrm{Ca}^{2+}$ might function by precipitating the liberated fatty acids as calcium salts.

Effects of various detergents and group-specific modifying agents on the lipase activity were 


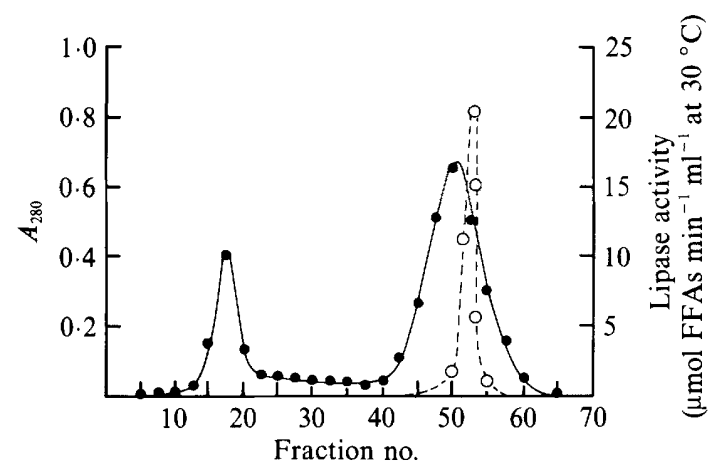

Fig. 1. Purification of lipase by gel filtration using Sephadex $\mathrm{G}+100$. The fractions with lipase activity greater than $10 \mathrm{U} \mathrm{ml}^{-1}$ (nos 51-53) were pooled. $A_{280} ; \bigcirc$, lipase activity.

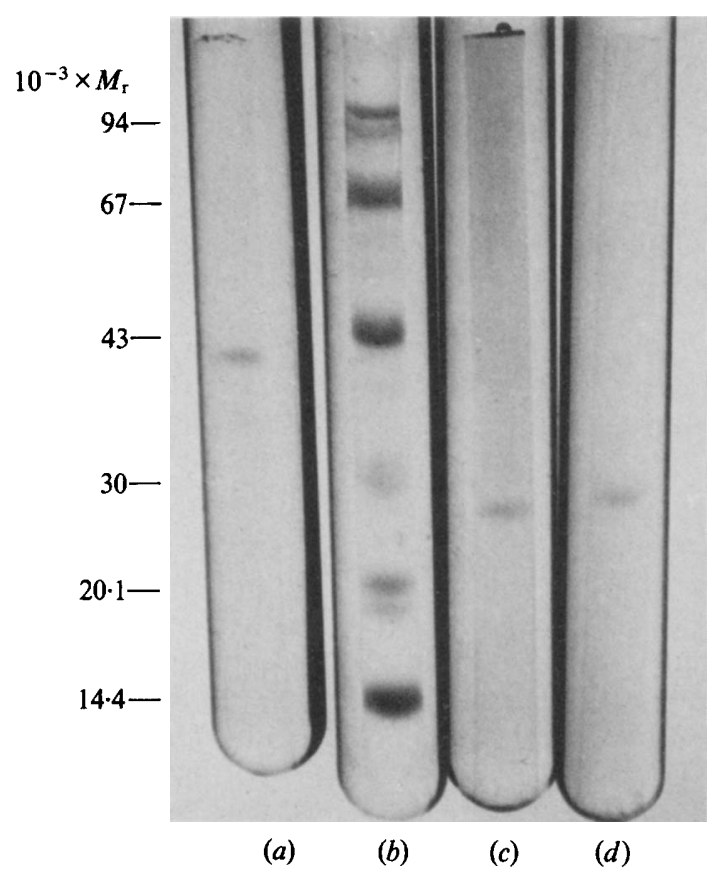

Fig. 2. (a) PAGE (7.5\% polyacrylamide) of native lipase; (b) SDS-PAGE of marker proteins (from top): phosphorylase, BSA, ovalbumin, carbonic anhydrase, soybean trypsin inhibitor and $\alpha$ lactalbumin; (c) SDS-PAGE of purified lipase and $(d)$ isoelectric focusing of purified lipase.

Table 1. Purification of N. crassa lipase

Saline extract

Charcoal treatment and dialysis Sephadex G-100 filtration

$\begin{array}{ccccc}\text { Total } & \text { Yield of } & \text { Total } & \begin{array}{c}\text { Specific } \\ \text { activity }\end{array} \\ \begin{array}{c}\text { protein } \\ (\mathrm{mg})\end{array} & \text { protein } & \text { activity } & {[\mathrm{U}(\mathrm{mg}} & \text { Purification } \\ & (\%) & (\mathrm{U}) & \left.\text { protein })^{-1}\right] & (- \text { fold })\end{array}$

$\begin{array}{lll}50 & 100 & 85\end{array}$

$\begin{array}{lll}35 & 70 & 75\end{array}$

$\begin{array}{lr}1 \cdot 7 & - \\ 2 \cdot 14 & 1 \cdot 25 \\ 44 & 25 \cdot 88\end{array}$


Table 2. Positional specificity of lipase

\begin{tabular}{|c|c|c|c|}
\hline \multirow[b]{3}{*}{ Fatty acid } & \multicolumn{3}{|c|}{ Fatty acid content $(\%$ of total wt) } \\
\hline & & \multicolumn{2}{|c|}{$\begin{array}{c}\text { Lard TG after treatmen } \\
\text { with } N \text {. crassa lipase }\end{array}$} \\
\hline & Lard TG & MG & FFA \\
\hline $14: 0$ & $3 \cdot 3$ & $5 \cdot 1$ & ND \\
\hline $16: 0$ & $19 \cdot 2$ & $64 \cdot 4$ & ND \\
\hline $18: 0$ & $12 \cdot \overline{5}$ & $25 \cdot 5$ & ND \\
\hline $16: 1$ & $2 \cdot 8$ & 0.5 & $1 \cdot 0$ \\
\hline $18: 1$ & $52 \cdot 8$ & $0 \cdot 8$ & $96 \cdot 8$ \\
\hline $18: 2$ & $8 \cdot 6$ & $2 \cdot 6$ & $2 \cdot 0$ \\
\hline
\end{tabular}

studied. Many lipases have been reported to be affected by detergents, but in this case DOC $(0 \cdot 1 \%$ and $1 \%, w / v)$ and SDS $(2$ and $20 \mathrm{~mm})$ did not affect lipase activity. Activity was not inhibited by thiol-binding reagents like PCMB $(0 \cdot 1 \mathrm{mM})$, NEM (10 mM) and DTNB (1 mM), suggesting the absence of thiol groups at the active site of the lipase. Similar results have been reported for the lipase from Staphylococcus aureus (Muraoka et al., 1982). TNBS (1 mM) inhibited $90 \%$ of the lipase activity. Besides amino groups, TNBS is known to react with thiol groups also, but under alkaline conditions ( $\mathrm{pH} \mathrm{9.5)} \mathrm{the} \mathrm{thiol} \mathrm{derivative} \mathrm{is} \mathrm{unstable}$ (Glazer et al., 1975). Modification with TNBS was done at pH 9.5 (50 mu-borate buffer) followed by dialysis against assay buffer $(50 \mathrm{~mm}-\mathrm{Tris} / \mathrm{HCl}, \mathrm{pH} 7 \cdot 0)$. The results suggested that free amino groups are required for the maintenance of enzyme activity.

\section{Influence of the nature of fatty acids on the rate of hydrolysis}

The effect of chain length as well as unsaturation of fatty acids on lipase activity was studied using different triacylglycerols. Five different sets of assays were done in each case. The $N$. crassa lipase preferred tripalmitin, tristearin, tripalmitolein, triolein and trilinolein and hydrolysed these at almost the same rates $\left(40-44 \mu \mathrm{mol} \mathrm{mg}^{-1} \mathrm{~min}^{-1}\right)$. TGs with short-chain fatty acids $\left(\mathrm{C}_{4}, \mathrm{C}_{6}, \mathrm{C}_{8}, \mathrm{C}_{10}\right)$ were hydrolysed at a very slow rate $\left(10-16 \mu \mathrm{mol} \mathrm{mg}^{-1} \mathrm{~min}^{-1}\right)$. Preference towards TGs with long-chain fatty acids $\left(\mathrm{C}_{16}, \mathrm{C}_{18}\right)$ appears to be metabolically significant since these fatty acids are the most abundant in fungal lipids, palmitic acid $(28.4 \%)$ and linoleic acid $(42.5 \%)$ being the major fatty acids in TGs of $N$. crassa (Kushwaha \& Kates, 1976). Such preference towards substrates containing endogenously occurring fatty acids has also been reported in the case of several seed lipases (Lin et al., 1986). Substrate specificity has been demonstrated in the case of some other microbial lipases (Mudherwa et al., 1985). Triolein is more rapidly hydrolysed than tristearin by the lipases of Candida paralipolytica, Corynebacterium acnes and Candida deformans (Mudherwa et al., 1985), and the lipase from Propionibacterium acnes hydrolyses trilaurin, triolein, trimyristin and tripalmitin at decreasing rates (Ingham et al., 1981). The greater solubility and physical characteristics of the TGs of shorter fatty acids, such as $\mathrm{C}_{10}$ and $\mathrm{C}_{12}$, often make them more suitable substrates for lipases such as pancreatic lipase (Lin et al., 1986). However, in this case tripalmitin and tristearin were better substrates than tricaprin or trilaurin in spite of their lower solubility.

\section{Positional specificiy of the lipase}

Positional specificity of the lipase was determined using lard TG as substrate. It contains long-chain saturated fatty acids $(16: 0$ and $18: 0)$ in position 2 and mainly oleic acid $(18: 1)$ in positions 1 and 3 . The GLC analysis (Table 2) revealed that MGs produced by the $N$. crassa lipase-mediated hydrolysis contained mainly saturated fatty acids, while the FFA fraction was only oleic acid. This result suggests that the $N$. crassa lipase preferentially cleaves the primary ester group of triacylglycerols in the same way as pancreatic lipase (Brockerhoff \& Jensen, 
1974b) and the lipases from Rhizopus arrhizus (Benzonana, 1974), Candida deformans (Mudherwa et al., 1985) and different Alcaligenes strains (Kokusho et al., 1982).

Microbial lipases have received much attention in recent years because of their application in industry and medicine, but their physiological relevance has not been studied in detail. Using mixed TGs, lipases from several seed species have been shown to be relatively specific for substrates containing the major fatty acid components of the storage triacylglycerols of the same species (Lin et al., 1986). Such studies on the significance of substrate specificity of microbial lipases are scant. The preference of the $N$. crassa lipase for substrates containing endogenously occurring fatty acids suggests the need to extend these studies using mixed TGs to determine whether microbial lipases are relatively specific for the characteristic TGs of the same species.

This work was supported by the Department of Science and Technology, Government of India. The authors are grateful to Dr A. Ghosh, Reader, Department of Chemistry, for a generous gift of some of the substrates.

\section{REFERENCES}

Benzonana, G. (1974). Some properties of an exocellular lipase from Rhizopus arrhizus. Lipids 9, 166172.

Brockerhoff, H. \& JeNSEN, R. G. (editors) (1974a). Lipases. In Lipolytic Enzymes, p. 30. New York: Academic Press.

BrockerhofF, H. \& JenSEN, R. G. (editors) (1974b). Pancreatic lipase. In Lipolytic Enzymes, pp. 55-56. New York: Academic Press.

Chakravarti, D. N., Chakravarti, B. \& ChakraBARTI, P. (1980). Studies on phospholipase activities in Neurospora crassa mycelia. Lipids 15, 830-837.

Chakravarti, D. N., Chakravarti, B. \& ChakraBARTI, P. (1981). Studies on phospholipase activities in Neurospora crassa conidia. Archives of Biochemistry and Biophysics 206, 392-402.

DAvIS, B. J. (1964). Disc electrophoresis II. Annals of the New York Academy of Sciences 121, 404-427.

Dole, V. P. \& MeINerTZ, H. (1960). Microdetermination of long chain fatty acids in plasma and tissues. Journal of Biological Chemistry 235, 2595-2599.

EBERHART, B. M. \& BECK, R. S. (1970). Localization of the $\beta$-glucosidases in Neurospora crassa. Journal of Bacteriology 101, 408-417.

EbERHART, B. M. \& BeCK, R. S. (1973). Induction of $\beta$ glucosidases in Neurospora crassa. Journal of Bacteriology 116, 295-303.

Glazer, A. N., Delange, R. J. \& Sigman, D. S. (1975). Modification of protein side chains: groupspecific reagents. In Laboratory Techniques in Biochemistry and Molecular Biology, vol. 4, part I, pp. 76-78. Edited by T. S. Work \& E. Work. Amsterdam: North-Holland Publishing Company.

Guchhait, M., Chakravarti, B., Chakravarti, D. \& Chakrabarti, P. (1983). Studies on an exocellular lipase activity in the conidia of Neurospora crassa. Indian Journal of Microbiology 23, 200-201.

HANKS, D. L. \& Sussman, A. S. (1969). The relation between growth, conidiation and trehalase activity in Neurospora crassa. American Journal of Botany 56, 1152-1159.

INGHaM, E., Holland, K. T., Gowland, G. \& Cunliffe, W. J. (1981). Partial purification and characterization of lipase (EC 3.1.1.3) from Propionibacterium acnes. Journal of General Microbiology 124, 393-401.
KoKusho, Y., Machida, H. \& Iwasaki, S. (1982). Studies on alkaline lipase: isolation and identification of lipase producing microorganisms. Agricultural and Biochemical Chemistry 46, 1159-1164.

Kushwaha, S. C. \& Kates, M. (1976). Lipid composition of Neurospora crassa. Lipids 11, 778-780.

Lin, Y. H. \& HuANG, A. H. C. (1983). Lipase in lipid bodies of cotyledons of rape and mustard seedlings. Archives of Biochemistry and Biophysics 225, 360-369.

Lin, Y. H., YU, C. \& Huang, A. H. C. (1986). Substrate specificities of lipase from corn and other seeds. Archives of Biochemistry and Biophysics 244, 346-357.

LUdDY, F. E., Barford, R. A. \& RIEMENSCHNEIDER, R. W. (1960). Direct conversion of lipid components to their fatty acid methyl esters. Journal of the American Oil Chemists' Society 37, 447-451.

Mudherwa, J. M., Ratomashenina, R., Pina, M., Graille, J. \& Galzy, P. (1985). Purification and properties of the lipase from Candida deformans (Zach) Langeron and Guerra. Journal of the American Oil Chemists' Society 62, 1031-1036.

Muraoka, T., ANDo, T. \& OKudA H. (1982). Purification and properties of a novel lipase from Staphylococcus aureus 226. Journal of Biochemistry 92, 1933-1939.

Semeriva, M., Benzonana, C. \& Desnuelle, P. (1967). Purification of a lipase from Rhizopus arrhizus. Identification of two active forms of the enzyme. Biochimica et biophysica acta 144, 703-705.

Tomizuka, N., OTA, Y. \& Yamada, K. (1966). Studies on lipase from Candida cylindracea. Part I. Purification and properties. Agricultural and Biological Chemistry 30, 576-584.

TsujIsaKa, Y., Iwal, M. \& TominaGa, Y. (1973). Purification, crystallization and some properties of lipase from Geotrichum candidum Link. Agricultural and Biological Chemistry 37, 1457-1465.

WEBER, K. \& OSBORN, M. (1969). The reliability of molecular weight determination by dodecyl sulfatepolyacrylamide gel electrophoresis. Journal of Biological Chemistry 244, 4405-4412.

WRIGLEY, C. W. (1976). Isoelectric focusing/electrophoresis in gels. In Isoelectric Focusing, pp. 93-117. Edited by N. Catsimpoolas. New York: Academic Press. 